Mini Review

\title{
IMPREGNATION AS A METHOD FOR PRESERVATION OF RELICS USED BY THE CHRISTIAN CHURCH
}

\author{
N. Tomov ${ }^{1 *}$, N. Dimitrov ${ }^{1}$, D. Atanasova ${ }^{1,2}$, J. (Yanko) Dzhangozov ${ }^{3,4}$ \\ ${ }^{1}$ Department of Anatomy, Faculty of Medicine, Trakia University, Stara Zagora, Bulgaria \\ ${ }^{2}$ Institute of Neurobiology, Bulgarian Academy of Sciences, Sofia, Bulgaria \\ ${ }^{3}$ Archimandrite, Bulgarian Orthodox Church - Patriarchate of Bulgaria \\ ${ }^{4}$ Department of Historical and Practical Theology, Faculty of Orthodox Theology, \\ St. Cyril and St. Methodius University of Veliko Tarnovo, Veliko Tarnovo, Bulgaria
}

\begin{abstract}
Relics are a special type of human body remains, which are venerated by the faithful due to the prominence the person had achieved during lifetime. Even if no such claims for incorruptibility are made, body relics have to be preserved in some fashion, in order to allow for their long-term viewing and veneration. The present report summarizes the available data regarding the impregnation as a method for body preservation, used by the Christian Church to conserve body relics. Impregnation is a widely used method, both by the Orthodox as well as by the Roman Catholic Church. It is known that bodies are treated with different protective mixtures on variable intervals after death. Public worship historically involved pouring of oil over relics. Moreover, small tissue fragments are embedded in wax blocks or are sealed with a mixture of molten wax and other resins. All of those methods are in fact impregnation with compounds with high molecular mass as a final stage of a preservation procedure. This impregnation of a tissue already reached some degree of dehydration or other preservation ensures longevity and protection of the relics by greatly slowing down the natural processes of decomposition and disintegration.
\end{abstract}

Keywords: relics, impregnation, mummification, reliquary, Christianity

\section{INTRODUCTION}

Preservation of the body after the physical death is a widespread practice since prehistoric times. Most of the ancient preservation methods involve removal of internal organs, brain, and/or adipose tissue, with subsequent treatment of the remains. Essentially the same procedures are followed in modern embalming and plastination (1).

Usually the artificial methods of preservation are additive to the environmental factors, such as low temperature, low humidity, air currents, and/or insulation of the body, which facilitate preservation. Regardless of the details, body preservation always follows the three main steps of fixation, dehydration and impregnation (2), with only slight differences concerning the methods used.

*Correspondence to: Dr Nikola Tomov, Department of Anatomy, Faculty of Medicine, 11 Armeyska Str., 6000 Stara Zagora, Bulgaria, tomovmd@gmail.com
Preservation of bodies and parts of them is especially important in the Christian Church, due to the fact that the body relics are vigorously revered by the faithful. The spiritual importance of the relics is outlined by the Fathers of the early Church such as St John of Damascus (3) and theologically explained by the Roman Catholic friar Thomas Aquinas (4). Sometimes the bodies of saints seemingly defy the normal decomposition process and are preserved to some extent, which is usually interpreted as a proof of sanctity.

Celebration of the Eucharist is possible only in the presence of relics (5). Furthermore, they are commonly displayed to the faithful for adoration. Therefore, their availability and preservation is of great practical importance (6). Due to the fact that relics are biological tissues their preservation is ought to follow the principles documented in other cases of preservation, of which impregnation is the final and conclusive step (2). 
The aim of the present report is to summarize and analyze the impregnation techniques used by the Christian Church for preservation of body relics.

\section{IMPREGNATION OF WHOLE BODY RELICS AND LARGER PARTIAL RELICS}

The Roman Catholic Church has used historically a variety of methods for body preservation. They often include embalming solutions and covering the surface of a pretreated body with impregnating substances, such as balsam (7). This creates a hydrophobic layer on top of the body, which could be sufficiently impregnating the skin and soft tissues to ensure at least a partial preservation.

The Orthodox Church relies mostly on natural preservation of dead bodies. Only after a body is recovered as a relic, it can be treated subsequently, regardless of its preservation state. For instance, some local churches perform a ritual called "washing the relics". While nowadays it is performed by pouring water over relics, its Byzantine original called for pouring of oil over them, done during a special service (8). Such "washing" is nothing different than a periodically repeated process of impregnation with lipid compounds. Olive oil, which was traditionally used, is natural oil, derived from the fruits of olive trees (Olea europaea). It contains mainly fatty acids, as well as multiple lipid soluble substance such as carbohydrates, sterols, alcohols, tocopherols, and pigments, along phenolic and other volatile compounds, some of which could possess preserving properties (9).

It is highly likely that "washing the relics" could have involved not only olive oil, but also some amount of myron. Myron (also called chrism) is a special mixture, based on olive oil and wine, containing aromatic resins, herbs, roots, etheric oils and essences. The ingredients of myron vary dependent on the local practice. The Patriarchate of Constantinople utilizes a formula claimed to originate from the ancient Jewish prophets and containing 64 different compounds (10).

"Washing the relics", actually pouring oils over them, leads to an impregnation of dehydrated tissues with oily substances. The process of impregnation consolidates the relics and creates a hydrophobic film on their surface which protects the integrity of the relic. The impregnation could have been enhanced with etheric oils and aromatic resins, which possibly act as preservatives and inhibit bacterial and fungal growth.
TOMOV N., et al. IMPREGNATION OF SMALL PARTIAL BODY RELICS

The smallest partial body relics are kept in small containers, made of metal, glass, or, in more modern times, plastic. The variable size and condition of the relics has led to the practice of embedding them in small disks/blocks of wax or other natural compounds. (Figure $1 \mathrm{~A}, \mathbf{B}, \mathbf{C}, \mathbf{D})$. Following their embedding they can be placed in bigger reliquaries (Figure $2 \mathrm{~A}, \mathbf{B}, \mathbf{C}, \mathbf{D}$ ), or built in icons or other objects. Small pieces of relics are also sealed in every altar table on which the Eucharist is celebrated (11). Both instances involve the usage of a mixture of wax and other compounds called wax-mastic or ceromasticum. It is a cement-like substance which contains wax, mastic, mastic, myrrh, aloes, frankincense, rose oil, and occasionally marble dust (12). Natural beeswax is a complex mixture of carbohydrates, free fatty acids, fatty acid esters, alcohols and other substances $(13,14)$, which is well known to have antimicrobial properties (15). Wax, especially when it is molten, as in the case of pouring the wax-mastic over relics, can sufficiently impregnate smaller tissue pieces. The additives in the wax-mastic probably enhance its natural preserving effects.

Embedding in wax or wax-mastic reminds of the modern process of paraffin embedding for histology, which protects and facilitates further processing of a fixed and dehydrated piece of tissue. Paraffin, which is also sometimes used for impregnation of relics, is a mixture of petroleum-derived carbohydrates (16) and is capable of impregnation just like natural beeswax, thus being an analogue to wax in this process.

\section{DISCUSSION AND CONCLUSIONS}

The essence of all described techniques is impregnation of a previously dehydrated biological tissue, regardless of its state of preservation. The practices lead to infiltration of the tissue with substances with high molecular mass. Lipids create a hydrophobic layer on the surface of the tissue, while resins and waxes solidify and consolidate it. This makes the relic relatively resistant to external influence. Other compounds, added to the oil or the wax, can additionally act bacteriostatic and amplify the effects of impregnation.

The Christian Church uses a variety of methods, which are classical examples of impregnation as a concluding step in the process of conservation of biological tissue. The result of these methods is protection of relics from environmental factors and the prevention of their natural disintegration. 


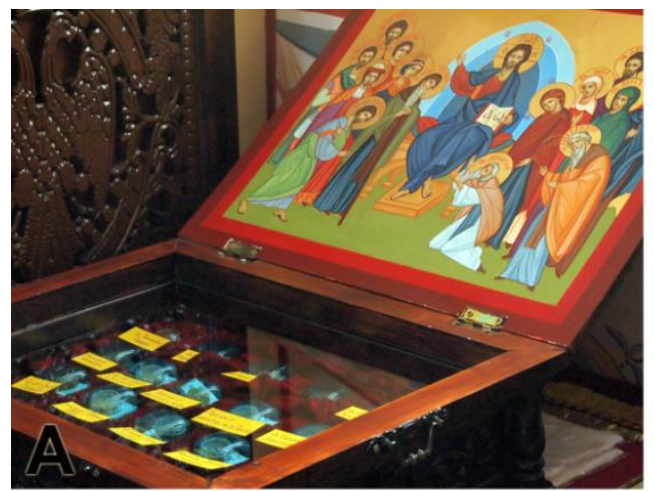

TOMOV N., et al.
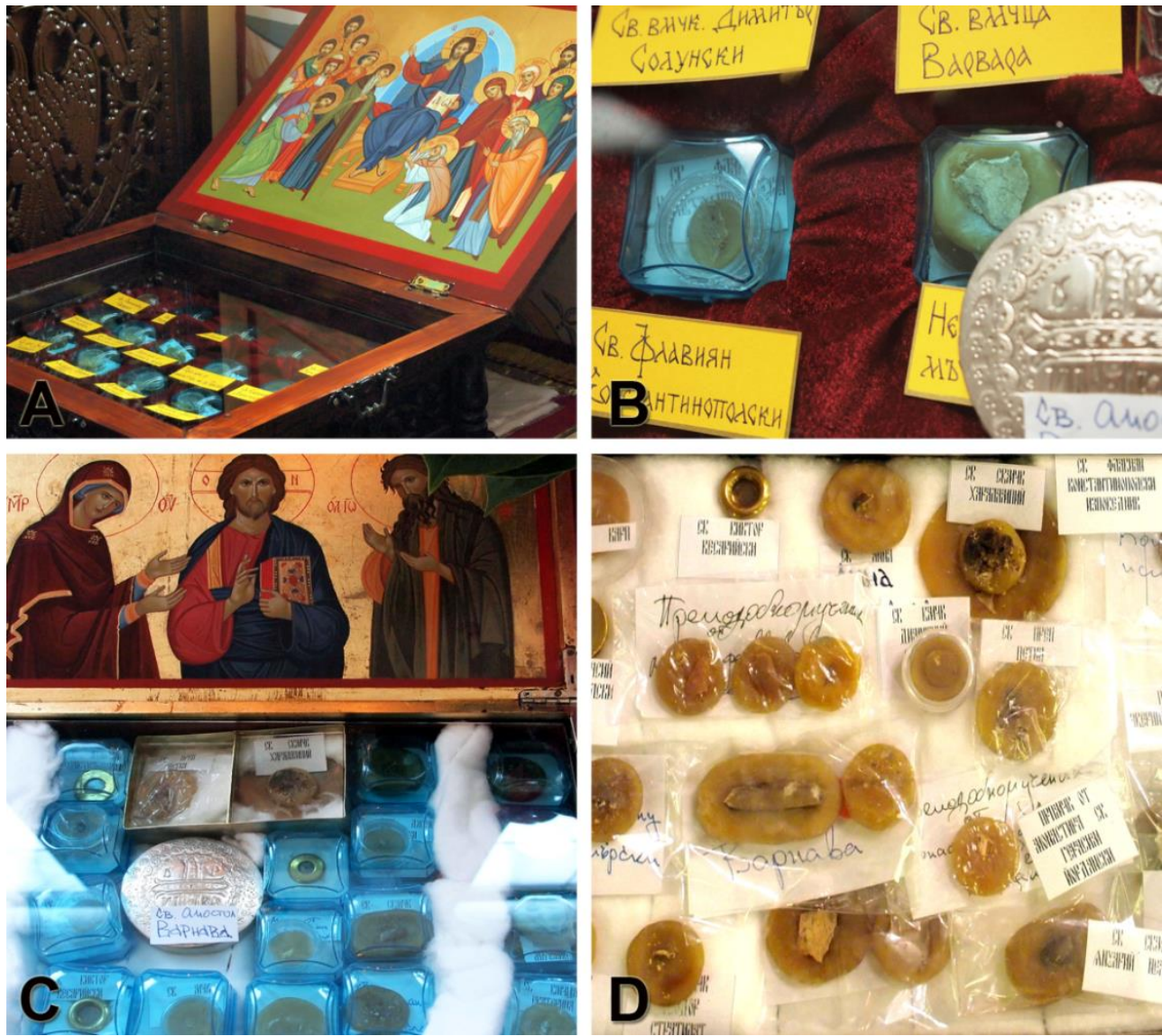

Figure 1. (A, B, C, D). Embedding of small partial body relics in blocks of wax.
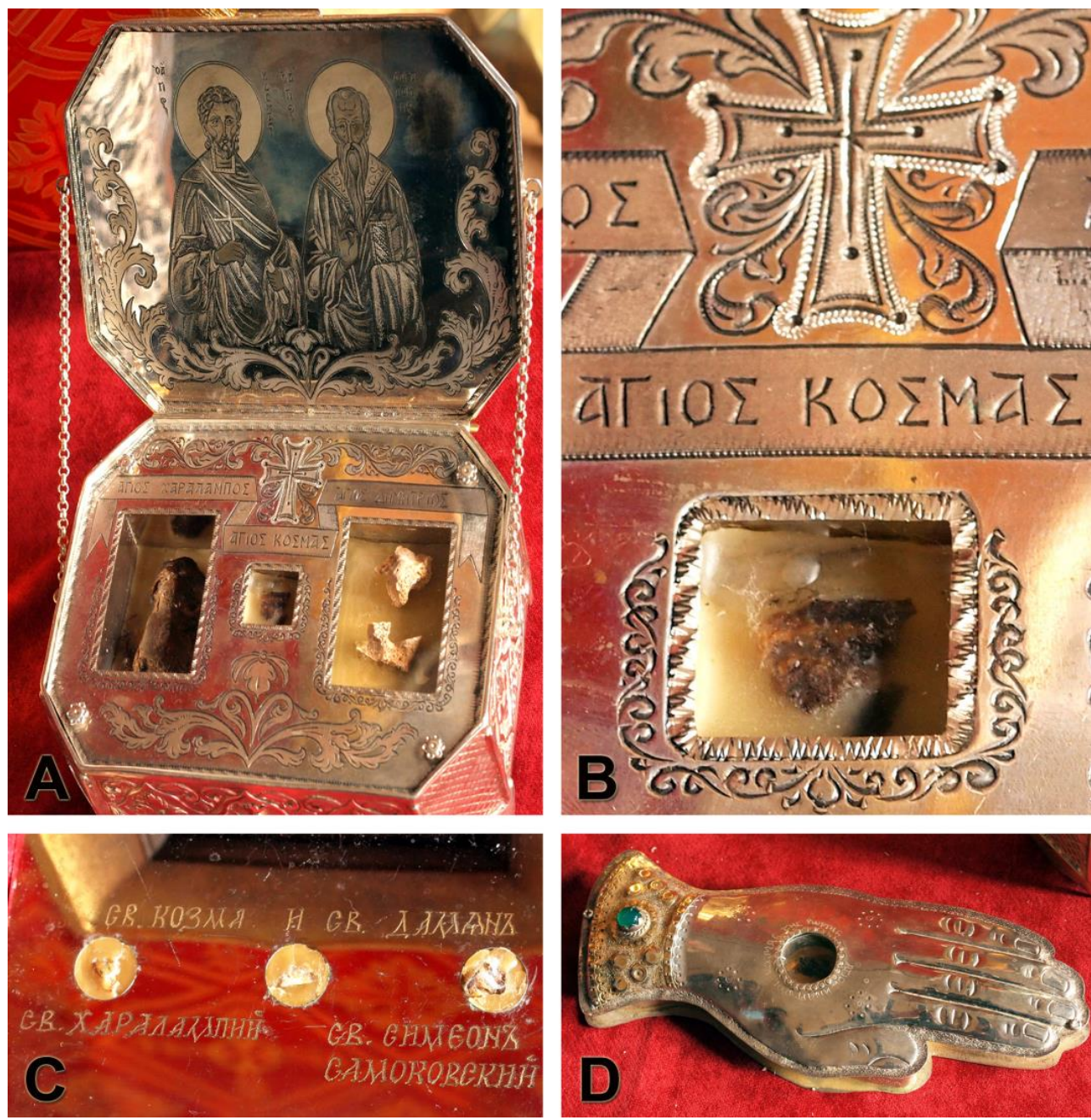

Figure 2. (A, B, C, D). Silver reliquaries containing wax-embedded partial body relics. 


\section{REFERENCES}

1. Sivrev, D., Miklosova, M., Georgieva, A. and Dimitrov, N., Modern day plastination techniques - successor of ancient embalmment methods. Trakia Journal of Sciences, 3(3):48-51, 2005.

2. Sivrev, D., Georgieva, A. and Dimitrov, N., From mummification to plastination. Acta morphologica et anthropologica, 10:288290, 2005.

3. Chase, F.H., Saint John of Damascus: Writings. Catholic University of America Press, Washington, USA, 1958.

4. Aquinas, T., Summa Theologica. Benziger Bros, New York, USA, 1947.

5. Percival, H.R., The Seven ecumenical councils of the undivided church: their canons and dogmatic decrees, together with the canons of all the local synods which have received ecumenical acceptance. James Parker and Company, Oxford, England, 1900.

6. Dimitrov, N., Atanasova, D., Ivanova, I., Georgieva, A., Hamza, S., Stoyanov, J. and Sivrev, D., Methods for preservation of body relics used by the Christian Church. Science and Technologies, 2018 (in press)

7. Tomov, N. Preserving the Pontiff: an account of the body preservation methods used by the Roman Catholic Church. Acta Morphologica et Anthropologica, 25:117121, 2018.

8. Moussine, A., The worship of holy relics in Medieval Russia: liturgical aspect. In:

\section{TOMOV N., et al.}

Eastern Christian relics. Progress Tradition, Moscow, Russia, pp. 363- 385, 2003.

9. Boskou, D., Blekas, G. and Tsimidou, M., Olive Oil Composition. In: Boskou D (ed.), Olive Oil: Chemistry and Technology. AOCS Publishing, Urbana, USA, 2006

10.Alfeyev, H., Le Mystère de la foi. Cerf, Paris, France, 2001.

11.Krasnopevkov-Rumovskiy, V. The New Tablet of Testimony or An Explanation of the Church, the Liturgy and all Ecclesiastical Services and Utensils [in Russian]. Pochayiv Lavra, Pochayv, Ukraine, 2013

12.Tomov, N. and Dzhangozov, J.(Y)., Wax embedding as a method for preservation of body relics used by the Orthodox Church. Acta Morphologica et Anthropologica, 25:122-125, 2018.

13.Tulloch, A.P., The composition of beeswax and other waxes secreted by lipids. Lipids 5:247-258, 1970.

14.Tulloch A.P., Beeswax - composition and analysis. Bee World, 61:47-62, 1980

15.Fratini, F., Cilia, G., Turchi, B. and Felicioli, A., Beeswax: A minireview of its antimicrobial activity and its application in medicine. Asian Pac J Trop Med, 9(9):839843, 2016.

16.Freund M. and Mózes, G., Paraffin products: properties, technologies, applications. Elsevier, Amsterdam, Netherlands, 1982. 